Kirja-arviot

\title{
Eurooppalaiset ihmesadut ja tutkimushistorian ihmeet
}

Apo, Satu. 2018. Ihmesatujen historia. Näkökulmia kirjailijoiden, kansankertojien ja tutkijoiden traditioon. Helsinki: Suomalaisen Kirjallisuuden Seura. 408 sivua.

\section{Venla Sykäri}

I

hmesatujen historia on kirjana harvinaista herkkua: se on erinomainen tietokirja, joka johdattaa lukijan sekä suullisten että kirjallisten kertojien luomien ihmesatujen pariin alkuperäisaineistojen avulla. Lisäksi se tarjoaa analyysiin perustuvan syväsukelluksen suullisen ja kirjallisen ilmaisun vuorovaikutukseen sekä tämän vuorovaikutuksen ideologisesti jännitteiseen tutkimushistoriaan. Läpi teoksen on luettavissa eurooppalaisen varhaismodernin kulttuurin syvä sukupuolittuneisuus, jonka vaikutukset yltävät aina ihmesatujen henkilöhahmojen kuvauksesta kirjoittajien ja kansankertojien asemaan sekä tutkimuksen painopisteisiin. Vastikään Kalevalaseuran palkinnon elämäntyöstään saanut folkloristiikan professori emerita Satu Apo on edistänyt sukupuolentutkimuksellista näkökulmaa molemmilla kentillään, sekä kalevalamittaisen

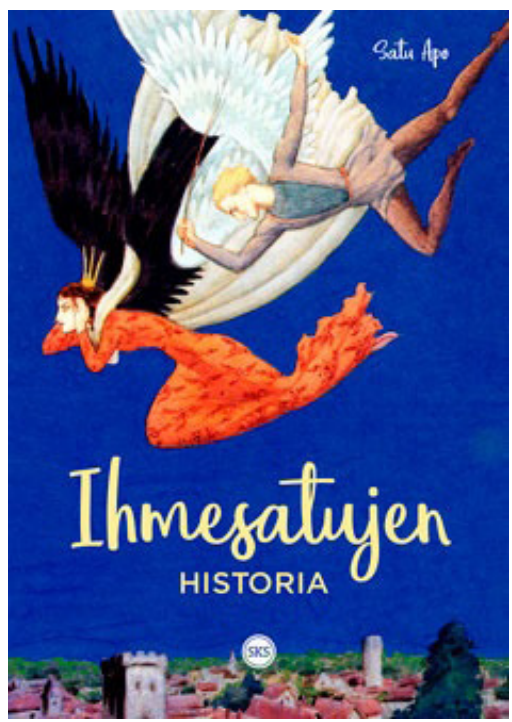
runouden että ihmesatujen tutkimuksessa. Ihmesatujen historia summaa näistä jälkimmäisen.

Kirjan keskiössä ovat ihmesaduista erityisesti tarinan "ryysyistä rikkauksiin" eli nopean sosiaalisen nousun sisältävät ja naisprotagonisteista kertovat "prinsessasadut". Aineiston valintaa ei liiemmin perustella, mutta ilmeistä on, että Apo on halunnut keskittyä tunnetuimpiin ja viihdeteollisuuden eniten hyödyntämiin satutyyppeihin. Ihmesadut nousivat 1800 -luvulla romantiikan myötä kirjallisuuden valtavirtaan, teattereihin ja oopperaan sekä 1900-luvun puolivälissä Walt Disneyn Lumikin innoittamina elokuvien suursuosikeiksi. Tutkijat ja lukijat ovat pitkään kuvitelleet ihmesatujen pohjautuvan ikiaikaisiin suullisiin kansankertomuksiin. Tällaisiksi satukokoelmien julkaisijat ja satututkimuksen pioneerit, etenkin Grimmin veljekset, 1800-luvulla tietoisesti ne profiloivat. Viiden eri ihmesadun analyysin myötä Apo kuljettaa lukijan antiikista varhaismoderniin Eurooppaan sekä 1800-luvulla alkaneesta 
satututkimuksesta 2000-luvun kuumimpaan debattiin. Tämän varsin tuoreen, vaikka nyt jo asettuneen, debatin sydämessä oli suullisen ja kirjallisen kerronnan suhde ja vaikutteiden suunta: saivatko ihmesatujen ensimmäisten kirjallisten versioiden tekijät 1500-1600 -luvuilla vaikutteensa kansankertomuksista - vai päätyivätkö ihmesadut suulliseen kerrontaan vasta painotuotteiden kautta levinneistä kirjallisista satuversioista?

Helsingin yliopiston folkloristiikan opiskelijat ja tutkijat saattoivat seurata aitiopaikalta tätä "suurta satusotaa": professori Satu Apo päivitti väittelyn vaiheita tuoreeltaan tutkijaseminaareissa pitämillään esitelmillä. Satusota syttyi, kun yhdysvaltalainen vanhan kirjallisuuden ja Grimmin satujen tutkija Ruth B. Bottigheimer julkaisi vuosina 2002 ja 2009 ilmestyneissä ihmesatujen historiaa käsittelevissä kirjoissaan teesinsä. Hän väitti, että ihmesaduissa suosittu sosiaalisen nousun tarina ei ollut lähtöisin kansankertomuksista vaan venetsialaisen kirjailijan Giovan Francesco Straparolan itse sepittämistä kertomuksista kokoelmassa Piacevoli notti (1550-1553). Yhdysvaltalaiset ja eurooppalaiset folkloristit, heistä Suomessa tunnetuimpana Dan Ben-Amos, nousivat vastarintaan puolustamaan ihmesatujen suullista alkuperää. Suurin debatti käytiin alan keskeisen lehden, Journal of American Folkloren, vuoden 2010 erikoisnumerossa. (s. 338-343.)

Satu Apo oli asioista hyvin perillä. Hänen 1986 valmistunut folkloristiikan alan väitöskirjansa käsitteli ihmesadun rakenteita, ja 1990-2000 -lukujen vaihteessa hän teki ihmesatujen historiaan liittyvää tutkimusta alkuperäislähteiden parissa. Kirjassa esitetyn kirjalliseen traditioon kohdistuvan analyysin perustana onkin 1600- ja 1700-lukujen eurooppalaisten satuklassikoiden tutkimus Italiassa ja Ranskassa, Rooman ja Pariisin kansalliskirjastoissa. Kirjan toinen keskeinen analyysikohde on ihmesatujen suullinen traditio. Apo analysoi suomalaisia, karjalaisia ja suomenruotsalaisia kansansatuja aineistonaan 1800-luvun tallenteiden kokoelmat Suomalaisen Kirjallisuuden Seuran ja Svenska litteratursällskapetin arkistoissa. Kaikki kirjan aineistonäytteet ovat saatavilla myös alkuperäiskielisinä. (s. 10,13.)

Temaattisesti kirja jakautuu johdanto-osuuden jälkeen kahtia: omat yksityiskohtaiset historialliset selvityksensä saavat sisältönsä osalta eriaikaiset kirjalliset ja suulliset versiot klassikkosaduista Cupido ja Psyche, Tuhkimo, Ruusunen, Kaunotar ja Hirviö sekä Lumikki. Kolmessa viimeisessä luvussa Apo tarkastelee 1800-luvulla syntyneen saduntutkimuksen vaiheita ja satujen tulkintoja 1800-luvulta 2000-luvulle.

\section{Johdatus ihmesatujen synnyn, leviämisen ja tutkimuksen historiaan}

Suullisesti kerrottuja satuja on muistiinpantu 1800-luvun alkupuolelta alkaen, mutta tallennus vauhdittui vasta satujen tieteellisen tutkimuksen vilkastuttua 1800-luvun loppupuolella. Suullisesti esitettyjen satujen sisällöstä tiedetään siten ajalta ennen 1800-lukua kovin vähän. Antiikin aikaan genre oli leimattu arvottomaksi, lapsia hoitavien naisten, vanhojen akkojen ja imettäjien tarinoiksi. Keskiajalla kritiikkiä lisäsi se, että satujen fantasia-aiheet kilpailivat kristinuskon yliluonnollisten ihme-elementtien kanssa. 1600- ja 1700-luvun vaihteen Ranskassa satujen kirjoittamisesta tuli ylhäisönaisten keskuudessa muotia, mutta naisten asema kirjoittajinakaan ei tuonut lajille meriittiä. Kirjallisten tuotoksien kautta klassikko-aseman saavuttaneiden satujen kenttää ovatkin hallinneet miehet. Kun suullisten satujen tallennus alkoi 1800-luvulla, myös suurin osa niistä tallennettiin mieskertojilta. (s. 18-19.) 
1800-luvulla ihmesatujen iästä kiinnostuttiin, ja vertailukohtia etsittiin sekä alkuperäiskansojen suullisesta perinteestä että Aasian korkeakulttuurien kirjallisuudesta. Vaikka yliluonnolliset elementit ovat kaikkialla yleisiä, ei vastineita eurooppalaiselle inmesatutraditiolle juurikaan löydetty. Antiikin Kreikan tai Rooman kirjallisuuden kertomuksien juonista ei myöskään ole löydetty myöhempiä ihmesatuja vastaavia kokonaisuuksia, vaikka yksittäisille episodeille ja motiiveille onkin useita vastineita. Lähimpänä ihmesatuja on roomalaisen Lucius Apuleiuksen kertomus Cupidosta ja Psychestä. Myöskään keskiaika ei Apon mukaan ole inmesatukirjallisuuden syntyaika, vaikka kuninkaita, ritareita, velhoja ja magiaa sisältävä kertomusmaailma sinne inmesaduissa usein sijoitetaankin eikä fantasia-aihelmista ollut tuolloin puutetta.

Vasta kirjapainotaidon käyttöön tulo ja painatteiden saatavuus sekä tämän myötä alemmista säädyistä koostuva uusi yleisö muuttivat 1500-luvulta lähtien myös fantasiakertomusten sisältöä: ihmesadut, joissa köyhät tytöt ja pojat nousevat kuninkaiksi ja kuningattariksi, alkoivat yleistyä, koska tällaiset sankarihahmot puhuttelivat laajentunutta lukijakuntaa. Ensimmäinen ihmesatuja sisältävä kirjallinen kertomuskokoelma on venetsialaisen kirjailijan Giovan Francesco Straparolan (n. 1480-1558) teos Le piacevoli notti (Rattoisat yöt). Tämä teos, joka sisältää muun muassa Saapasjalkakissana myöhemmin tunnetun ihmesadun, loi ihmesadun genren eurooppalaiseen kirjallisuuteen.

Apo toteaa, että Straparolan kokoelman ainesten alkuperää ei lähteiden puuttuessa voida saada selville, mutta se tiedetään, että teoksen myötä köyhät satusankarit nousivat pysyvästi lajin kirjalliseen kaanoniin. Edullisten painotuotteiden saatavuus mahdollisti myös naiskirjailijoiden esiinnousun. Ranskassa aateliset naiset, tunnetuimpana paronitar d'Aulnoy (16501705), kirjoittivat fantasiaromaaneja sekä haltiatarsatuja. Huokeat painotuotteet levisivät kirjoina ja vihkosina, satuja muokattiin yhä uusiksi versioiksi ja suosituimmat käännettiin nopeasti eri kielille. Kun perinteentutkimus kiinnostui saduista, oli painettu satukirjallisuus siten vaikuttanut suulliseen kerrontaan Euroopassa jo usean vuosisadan ajan. (s. 36-42.)

Viihdekirjallisuus levisi arkkipainatteiden kautta 1700-luvulla myös Pohjoismaissa. Ensimmäiset suomenkieliset kirjalliset sadut ilmestyivät vasta 1840-luvulla, samaan aikaan, kun Grimmin veljesten aloittaman kansansatuinnostuksen myötä ensimmäiset kansansatukokoelmat kerättiin muissa Pohjoismaissa. Suomessa tallennettiin 1800-luvun alkupuoliskolla laajasti kalevalamittaista runolaulua, ja merkittävämmät satuaineistot koottiin vasta Kaarle Krohnin johdolla 1880-1890-luvuilla. Suomalaiset satukokoelmat ovat kuitenkin mittavia ja satutyyppien määrä suuri, sillä Suomeen on päätynyt satuja (kuten muutakin perinnettä) sekä Ruotsin kautta että itäistä, venäläis-karjalaista tietä. Näistä läntisen tradition arvioidaan olevan 1600-1700-luvulta; itäisen perinteen ikää ei ole voitu määrittää, mutta se saattaa olla läntistä vanhempaa. Apo esittelee Suomessa suosittuja aiheita, kertojia, alueita sekä tekstualisaation tapoja. (s. 42-60.)

\section{Viisi klassikkosatua}

Apuleiuksen kirjoittama Cupidon ja Psychen tarina ajanlaskun toiselta vuosikymmeneltä on kirjan ensimmäinen yksityiskohtaisesti analysoitu ihmesatu. Sadusta löytyy mielenkiintoisia yhtäläisyyksiä Vienassa ja Inkerissä lauletun runolaulumittaisen Marian virren kanssa (SKVR-hakemistossa nimellä Luojan virsi). Lisäksi Apo analysoi Laatokan Karjalasta 1879 
tallennettua versiota nimeltä Käärmesulhanen tarkastellen siitä löytyviä yhtäläisyyksiä sekä kotoistamisen prosessissa tulleita muutoksia. (s. 61-93.)

Seuraavaksi on vuorossa Tuhkimo, jonka tarina valloitti koko maailman viimeistään Disneyn ensimmäisen, vuonna 1949 tuotetun animaatioelokuvan myötä. Varhaisin juoneltaan nykyistä vastaava Tuhkimo-satu on kirjoitettu 800-luvulla kiinaksi, ja sen muistiinpanija ja kertoja edustavat todennäköisesti annamilaisia, nykyisiä vietnamilaisia. Euroopassa vanhin säilynyt Tuhkimo-satu ilmestyi 1634 napolilaisen Gianbattista Basilen teoksessa Pentamerone, joka on samalla vanhin kokonaan vain satuja sisältävä kokoelma. Teoksesta muodostui keskeinen lähde ranskalaisille kirjailijoille, kuten madame d'Aulnoylle ja Charles Perraultille. Myöhemmin saksalaiset Grimmin veljekset sisällyttivät kansansaduiksi naamioituihin satuihinsa runsaasti aineksia Basilen teoksesta. Todennäköisesti tätä tietä nämä ainekset saapuivat myös Suomeen. (s. 94-142.)

Basilen "Tuhkakissan", sitä 63 vuotta myöhemmin seuranneen ranskalaisen Perraultin Tuhkimon sekä edelleen Grimmien 1800-luvun alussa kansanomaistaman Tuhkimo-hahmon osalta Apo analysoi eri kirjoittajien tuottamien versioiden eroja yksityiskohtaisesti. Saman käsittelyn saavat seuraavassa luvussa samojen kirjoittajien versiot Ruususesta. Aika- ja kulttuurisidonnaiset erot luotaavat kiinnostavasti Euroopan historiaa: siinä missä italialaisen Basilen saduissa on seksuaalisuus avoimesti läsnä ja kerronta ilakoi rehevällä huumorilla ja murteella, ja ranskalaisen, Aurinkokuninkaan hovissakin palvelleen Perraultin sadut esittelevät tyylikkäästi aristokraatin hienouksia, ovat 1800-luvun alussa satujen kirjoitustyön aloittaneiden Jacob ja Wilhelm Grimmin henkilöt ja miljööt tietoisen askeettisia ja maalaisia. Grimmien satuihin ideologisin päämäärin tuottamat muutokset korostavat protestanttista moraalia, siveää ja nöyrää naiskuvaa sekä satujen kansanomaisuutta. Tuhkimon osalta Apo tarkastelee lisäksi Suomen ja Karjalan kansankertojien kertomia Tuhkimo-satuja (s. 132-140) ja Ruususen osalta Topeliuksen 1870 ilmestynyttä satunäytelmää (s. 168-173).

Ranskan valtasi 1700-luvulla suuri innostus satujen kirjoittamiseen: tunnettuja malleja hyödyntäen aristokraatit tuottivat yhä uusia kertomuksia. Apon mukaan kuitenkin vain harva näistä nousi klassikon asemaan. Tärkein ja tunnetuin uutuus oli Kaunotar ja Hirviö, jonka luomisesta vastasivat kaksi naispuolista kirjailijaa. Ensimmäisen kertomuksen kirjoitti Gabrielle-Suzanne de Villeveuve 1740. Hän loi pitkän ja seikkaperäisesti kuvaillun tarinansa tapahtumapaikaksi ihmeellisen lumotun linnan, jossa eliitille mahdolliset ylellisyydet yhdistyvät aikansa luonnontieteen tutkimusten tuloksiin. Lyhyen ja tiiviin, nykyisin tunnetun version sadusta muokkasi kotiopettajana toiminut Jeanne-Marie Leprince de Beaumont 1756. Hän halusi tarjota aatelistytöille juuri heille sopivaa luettavaa ja valjasti sadun sisältämän emotionaalisesti rikkaan ihmissuhteiden kuvauksen opastamaan tyttöjä miehen valinnassa: Kaunottaren ja Hirviön tarina todistaa, että ulkonäön ja opittujen käytöstapojen sijaan tulee suosia hyvää luonnetta. Kirjallisten satuversioiden jälkeen Apo tutkii suomalaisten kansankertojien versioita sadusta sekä sitä, miten ranskalainen satu kotoistettiin Suomessa. (s. 200-206.)

Grimmin veljesten Lasten- ja kotisatuja -kokoelman maailmankuuluksi tekemä Lumikki on viimeinen kirjassa yksityiskohtaisesti käsiteltävä ihmesatu. Lumikin sepittäjäksi paljastuu kuitenkin saksalainen satujen kokoaja ja kirjoittaja Johann Carl August Musäus ja alkuperäisversioksi tämän 1782 julkaistu häijystä äitipuolesta kertova tarina Richilde. Musäuksen laajalevikkisen kokoelman kertomukset siirtyivät pian sekä suulliseen kerrontaan että 
näytelmäksi, jonka dramatisoi nuori kirjailija Albert Ludwig Grimm (ei sukua seuraaville). Tämän jälkeen tarinaan tarttuivat Jacob ja Wilhelm Grimm. Grimmin veljesten Lumikki-version yhteydessä Apo tarkastelee seikkaperäisesti molempien tutkijan- ja kirjailijanuria sekä heidän toteuttamaansa satujen kansanomaistamista. Lisäksi Apo analysoi sadusta muotoutunutta venäläistä runokertomusta Lauri Hongon perinteen sopeutumisteoriaa hyödyntäen ja tarkastelee suomalaisten ja venäjänkarjalaisten kansankertojien Lumikkia. (s. 245-258.)

\section{Satujen tutkimushistoria}

Ensimmäinen tutkimushistorialuku alkaa Eero Salmelaisen (Erik Rudbeck) vuonna 1857 julkaistun väitöskirjan aiheuttamasta skandaalista. Väitöskirja hylättiin plagioinnin takia, mutta skandaaliin liittyi myös väittely suomalaisten satujen alkuperästä. Monet tutkijat olivat jo todenneet, että suomalaiset kansansadut ovat kulkeutuneet maahamme naapurimaista, mutta Salmelainen puolusti aggressiivisesti niiden kotoperäisyyttä. Salmelainen ehti toimittaa moniosaisen klassikkoteoksensa Suomen kansan sadut ja tarinat ennen ennenaikaista kuolemaansa. (s. 259-262.)

Kansallisuusaate väritti varhaista saduntutkimusta monitahoisesti. Kuuluisimmat kulttuurinationalistit olivat tietysti Grimmit. He loivat kuvan yhdistyneestä Saksasta esittelemällä samojen kansien välissä kansankertomuksia, jotka oli 'löydetty' saksankielisen alueen eri puolilta. Veljekset eivät maininneet kertojien nimiä. Saksalaiset tutkijat saivat vähitellen selville, että Grimmit olivat käyttäneet lähteinään satukirjallisuutta sekä suullisesti kerrottuja ranskalaisia klassikkosatuja. Niitä esittivät veljeksille heidän ystäväpiiriinsä kuuluvat lukutaitoiset säätyläisneidot. Kansallisaatetta palvelevan kielihistoriallisen agendan ohella Grimmit painottivat satujen juontuvan ikiaikaisista myyteistä, mikä toi niille lisäarvoa. Apo esittelee ajan mytologiakeskustelua sekä monia muita satujen alkuperän etsintään liittyviä virtauksia. (s. 263-272.)

Vertaileva tutkimusote oli valtavirtaa 1800-luvun humanistisessa tutkimuksessa. 1880-luvun Suomessa kansanrunouden vertaileva tutkimus oli saavuttanut niin vahvan aseman, että siitä muodostui itsenäinen yliopistollinen oppiaine. Apo tarkastelee seikkaperäisesti eläinsaduista väitelleen Kaarle Krohnin sekä inmesatuihin erikoistuneen Antti Aarneen tutkimuksia. Ne johtivat maantieteellis-historiallisen menetelmän ja satutyyppiluettelon syntyyn. Samalla ne tekivät suomalaisen koulukunnan kansainvälisesti tunnetuksi. Itse menetelmä ja sen puutteet, kritiikki ja ansiot käydään läpi perusteellisesti. (s. 272-292.)

Tämän jälkeen Apo esittelee 1900-luvun uusia suuntauksia, joita olivat Arnold van Gennepin innoittamat riittiteoriat, Vladimir Proppin funktio-analyysi, Bruno Bettelheimin psykoanalyyttinen tulkintamalli, sosiaalihistorialliset tulkinnat sekä naistutkimuksen nousu (s. 293-321). Jälkimmäisestä Apo kirjoittaa kuvaavasti (s. 317): "Kun tutkijat ryhtyivät tarkastelemaan kansanperinteessä näkyvää sukupuolen esittämistä, löydöt eivät ilahduttaneet ketään".

Keskusteluissa vanhojen satujen sukupuolikuvista ei kuitenkaan alussa yleensä eroteltu suullisia kertomuksia ja kirjallisia tekstejä. Vasta 1980-luvulla kirjallisuudentutkija Ruth B. Bottigheimer alkoi selvittää tarkemmin, miten mies- ja naishahmot olivat muotoutuneet Grimmin veljesten käsissä. Vuosina 1812, 1819 ja 1857 ilmestyneistä satukokoelman versioista löytyi konkreettisia eroja naisten ja miesten puheen ja ajatusten esittämisen määrässä 
sekä sukupuolien erilaisesta suhteesta esimerkiksi käskyjen noudattamiseen. (s. 321-323.) 1800-luvulla luotu ihannekuva ydinperheelle omistautuneesta kotihengettärestä kirjautui siten myös ihmesatujen kuvastoon.

Käsitys ihmesatujen historiasta alkoi tarkentua 1970-luvulta lähtien uusien kokoelmien ja käännösten myötä. Kuitenkin vasta 2000-luvun alkuun sijoittuu merkittävämpi käänne, jonka ratkaisevana tekijänä oli kirjallisuuden tutkijoiden, muun muassa Bottigheimerin, uudet väitteet ihmesatujen lyhyestä historiasta ja kirjallisesta alkuperästä. Tämän "satusotaan" johtaneen debatin vaiheita ja väitteitä Apo ruotii kirjan lopuksi.

Lopputulemana Apo toteaa, että lähteiden puuttuessa on mahdotonta tietää, sisälsikö 12001500 -lukujen suullinen kerronta ihmesatuaiheita - ja missä määrin 1500-luvun ensimmäiset kirjalliset inmesadut perustuivat suulliseen perinteeseen. Koska suullisesta kerronnasta on kunnollisia aineistoja vasta 1800 -luvulta, on tätä aiempia aikoja koskevia pitäviä päätelmiä mahdotonta tehdä. 1800-luvulla puhtaan kansanomaisiksi naamioitujen ja monien sellaisina 2000-luvun alkuun saakka pitämien ihmesatujen kirjallisten juurien paljastuminen tarkoittaa joka tapauksessa, että yksinkertaistettujen tulkintojen aika on lopullisesti ohi. (s. 323-348.)

\section{Kulttuuri- ja tutkimushistoriaa terävästi ja tyylikkäästi}

Kirjan yksityiskohtaiset, aineistolähtöiset analyysit ovat vakuuttava todiste siitä, miten tiiviissä vuorovaikutuksessa kirjallinen ja suullinen ilmaisu elävät ja ovat aina eläneet. Vaikka aihetta on käsitelty viime vuosikymmenten aikana monilla suullisen, suullis-kirjallisen ja kirjallisen kulttuurin alueilla, Satu Apon kompakti teos inmesatujen historiasta on merkittävä puheenvuoro, joka selvittää asiaa juurta jaksaen. Ihmesatujen kansainvälisen tutkimushistorian analyysi palvelee folkloristeja, kirjallisuudentutkijoita ja kaikkia muitakin huomattavasti satututkimuksen kenttää laajemmin tarjotessaan selkeästi esitetyn näkökulman 1800- ja 1900-luvun tutkimushistorian keskeisiin paradigmoihin ja yksittäisiin virtauksiin. Teos sisältää hyvin tarpeellisen esityksen suomalaisen folkloristiikan tutkimushistoriasta, josta on saatavilla niukasti ajankohtaista tietoa suomen kielellä.

Kirjan läpäisevänä teemana naisen aseman ja koko kulttuurisen kentän sukupuolittuneen historian tarkastelu tarjoaa lukijalle alasta riippumatta yksityiskohtaisesti dokumentoidun, tarkkanäköisen analyysin tästä edelleenkin ajankohtaisesta näkökulmasta. Satujen eri versioiden, sekä kirjallisten että suullisten, sisällön analyysit ja vertaileva tutkimus havainnollistavat tehokkaasti aika- ja kulttuurieroja varhaismodernin ja modernin Euroopan eri maissa. Teoksen moniin ansioihin lukeutuu lisäksi harvinaisen suuri lukuilo: paitsi tietoa niin myös runsaasti huvia tuottaa Apon esittämä huumorilla höystetty yksityiskohtien kirjo, joka samalla järjestyy saumatta tutkimuskysymyksiä palvelevaksi todistusaineistoksi.

Folkloristiikan dosentti Venla Sykäri toimii Koneen Säätiön rahoittamana tutkijana Suomalaisen Kirjallisuuden Seuran tutkimusosastolla. Sykäri on erikoistunut suullisesti tuotetun runouden tutkimukseen, kohteenaan sekä nykykulttuurit että arkistoaineistot. Vuosien 2018-2020 aikana hän osallistui Avoimen Kalevalan eli vuoden 1849 Kalevalan digitaalisen kriittisen edition toteuttamiseen osana monitieteistä tutkimusryhmää. 